\title{
「棚田式魚道」における稚アユの遡上経路
}

\author{
馬㴊和三 1 ・板垣 博 $^{2} \cdot$ 平松 研 $^{3}$ ・清水英良 4
}

\section{Ascending Route of Juvenile Ayu at Terrace Type Fishways}

\author{
Kazumi Mabuchi ${ }^{1}$, Hiroshi Itagaki ${ }^{2}$, Ken Hiramatsu ${ }^{3}$ and Hideyoshi Shimizu ${ }^{4}$
}

\begin{abstract}
A fishway is a kind of facilities attached to a river-crossing structure to aid fishes to ascend it. The entrance of conventional pool-type fishway or fishslope is, however, located apart downstream from the facility, which often let fishes lose the entrance. A fan-shaped fishway and a terrace type fishway that is a modified form of the fan-shaped one are improved versions of pool-type fishway and fishslope whose entrances are widely opened in order for fishes to find them safely and surely. The effectiveness of their widely-opened entrance is known qualitatively by several surveys, whereas not known quantitatively. The aim of this paper is to confirm its superiority over the conventional ones by investigating the ascending routes of juvenile Ayu (Plecoglossus altivelis) at two terrace type fishways. The path of each fishway is spatially devided by sand bags into three routes, i.e. right side, center and left side and the number of ascending fish is counted by using video-cameras installed at the upper end of each route. As a result, $66.6 \%$ of acsended fish entered the fishways from sides. They might have lost the entrance, if the entrance were the conventional shape. The choice of route seemed to depend on location of the thalweg or gut. Ayus ascended only in daytime from noon to around 6 p.m. in both fishways, which might be due to water temperature, light intensity and their periodic habit. More than 1,000 Ayus ascending the fishways were seen in each day during the investigation period, which would indicate that these terrace type fishways works properly.
\end{abstract}

Keywords: Ayu, Ascending route, Fishway; Terrace type; River environment

\section{1 はじめに}

魚道は, 河川内における水棲動物, 主に魚類の移動障害 を除去・軽減するものであり，一般に河川構造物に附設 される施設である.17世紀には簡易な形態のものが設置 されたとの記録があり，300 年以上の歴史がある（Clay, 1995). その形式はしばしば，プールタイプ (階段式, バー チカルスロット型など), ストリームタイプ (斜路型, デ ニール型など), その他（ロック式など）の3 種類に分 類される. 西日本におけるアニなどの小型魚を対象とす る魚道では，プールタイプの一種である階段式の魚道が 比較的適していると考えられおり, 数多くの設置が見ら れる。また，特に河川上流では，維持管理の容易さから 粗石付斜路型魚道などの設置も数多く見られる。これら の魚道は設計時に想定する適切な条件下においては本来 の性能を発揮するはずであるが，過去に設置されたもの の中には機能不全に陷っているものも少なくない。これ らにおいては，「流量あるいは流速が適切でないため魚が 遡上できない」といった魚道内の遡上プロセスにおける 問題だけでなく,「堆砂あるいは洗掘により魚が魚道へ入

1 岐阜大学大学院連合農学研究科学生, 株式会社山辰組代表取締役 Graduate Student, The United Graduate School of Agricultural Science, Gifu University, 1-1Yanagido, Gifu 501-1193, Japan, President, Yamatatsu-gumi Construction Company, 203-1 Inabata, Ohno-cho, Ibi-gun, Gifu 501-0511, Japan

${ }^{2}$ 岐㚖大学応用生物科学部名誉教授 Professor Emeritus, Department of Environmental Science, Gifu University, 1-1Yanagido, Gifu 501-1193, Japan

3 岐皁大学応用生物科学部谁教授, Associate Professor, Department of Environmental Science, Gifu University, 1-1Yanagido, Gifu 501-1193, Japan (Corresponding Author) E-mail:hira@gifu-u.ac.jp

4岐阜大学応用生物科学部教授 Professor, Department of Environmental Science, Gifu University, 1-1Yanagido, Gifu 501-1193, Japan
れない」,さらには「魚が魚道入り口を見つけられない」 という魚道に入るまでのプロセス部分に問題を有してい ることが多い。

この問題に対して，魚道を折り返すことにより入り口 を河川構造物に近づける手法や開口部を扇形あるいは半 円状にして入り口を大きくする手法が考案され, 近年, こ れらを導入する事例が増えつつある。このうち, 後者は, 一般に扇形魚道（ダム水源地整備センター，1991; 和田, 2003）と呼ばれている階段式魚道との組み合わせが多い が，粗石付斜路型魚道の一部（ドイツ水資源・農業土木 協会，1996）やプールタイプとストリームタイプの両者 の特徵を有するハイブリット型魚道である「棚田式魚道」 においても同様の手法が導入されている. その流下状況・ 水理学的な条件は，たとえば，扇形魚道について Fujihara and Fujita(2009), 「棚田式魚道」については馬㴊ら（2003） の研究が見られるが, 一方で, 魚類の遡上に関する有効性 については定性的な評価しかされておらず，広くした開 口部が実際にどのように利用されているかについて，こ れまでに検証した例は見あたらない。

本研究では，両側回遊魚であるアユ（Plecoglossus altivelis） を対象魚として, 岐阜県西部を流れる根尾川の第 3 床固工および同地域を流れる牧田川の第 13 床固工に設 置された「棚田式魚道」において, 魚道への侵入䇢所を 確認することで，広くした開口部の有効性を明らかにす ることを目的とする。また，時系列計測数より，アユの 遡上特性についても言及する.

\section{2 対象魚道と調査条件}




\section{1 「棚田式魚道」}

「棚田式魚道」は，開口部を変形した半円状にすることで， 魚道正面からの侵入の他に, 堰堤に沿った方向からの侵 入も可能にしているほか，水深 $20 \mathrm{~cm}$ 程度のプール部を 有し，さらに縦方向の勾配 (1:10) と横方向の勾配 (1:6) を変えることにより，流量低下時においても遡上経路を 確保する点や, 流量や水位の変化に強く, 維持管理が容 易であるといらストリーム型と同様の利点を有している ことに特徵がある（馬㴊ら，2003）。現在，根尾川第 3 床 固工，牧田川第 13 床固工等に設置されているが，多くの アユの遡上が確認されており，比較的段差の小さな河川 構造物においては，階段式魚道に加えて，新たな選択肢 の一つになりうると考えられている（図 1）.

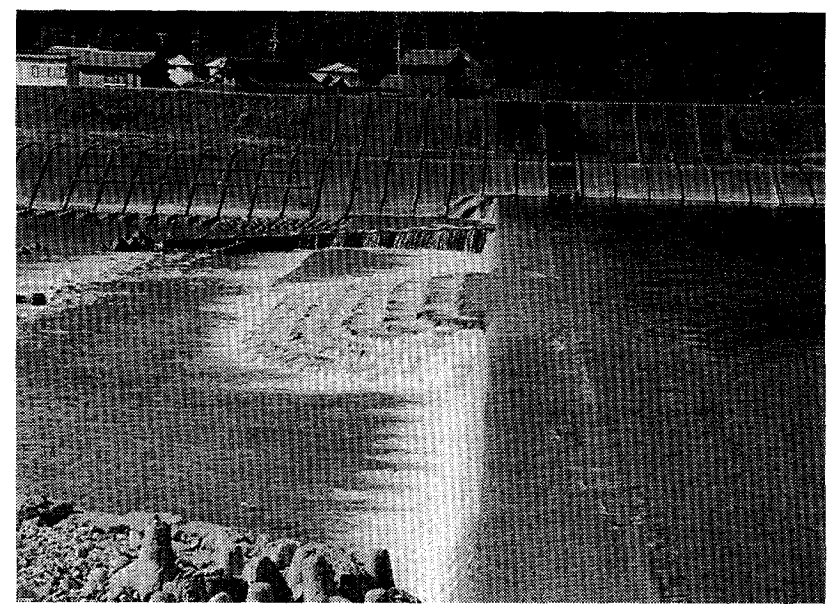

図 1: 根尾川に設置された棚田式魚道

\section{2 根尾川第 3 床固工設置の「棚田式魚道」}

当該魚道は, 1999 年に岐皁県本巣地域を流孔る根尾川の 第 3 床固工に設置されている（図 1,2）。根尾川第3 床固 工は揖斐川との合流点から約 $10.8 \mathrm{~km}$ 上流にあり，根尾川 管内で魚道が設置されている床固工のうちでは最上流に なる，床固工の全幅は $133.75 \mathrm{~m}$ であり，落差は $1.40 \mathrm{~m}$ と なっている. 当該魯道は河道中央部に設置されており，河 道方向の長さが約 $10.0 \mathrm{~m}$, 横断方向の長さが約 $32.7 \mathrm{~m}, 8$ 段のプールで構成されている。 また, 右岸には本魚道設 置前に設けられた $2.5 \mathrm{~m}$ 幅の階段式魚道があり, 河道右側 の一部を分離するような形となっている。この既設魚道 は，河床低下により上り口に落差が生じている上に，そ の先の下流部には土石が堆積しており，遡上が困難な状 況になっている. 近辺で見られる主な魚種は，アユ，ア マゴ, オイカワ, ヨシノボリ類, カジカ, ウナギとされ ている。

調查法平成 14 年 5 月 24 日から 5 月 26 日にかけて行い, 時間は午前 5 時から午後 7 時までとした。調查期間は 26 日に一時昙りとなったほかは晴天であり, 日中の平均気 温は $23^{\circ} \mathrm{C}$, 水温は, 調查を開始する午前 5 時に $15^{\circ} \mathrm{C}$ 程 度, 午後 5 時から午後 7 時が最も高く, $19^{\circ} \mathrm{C}$ 程度になっ ていた。第 3 床固工上流部に設置された量水標での水深 は，5月 24 日から順に $36 \mathrm{~cm}, 33 \mathrm{~cm}, 32 \mathrm{~cm}$ であり, 流量 は同じく $26.84 \mathrm{~m}^{3} / \mathrm{s}, 24.56 \mathrm{~m}^{3} / \mathrm{s}$ から $23.20 \mathrm{~m}^{3} / \mathrm{s}$ であった。 調查期間中は水深, 流量ともにやや減少傾向にあるが, 流 況としては大きな違いは見られなかった。これまでの調 查により当日の魚道入り口の平均流速は $75 \mathrm{~cm} \cdot \mathrm{s}^{-1}$ 程度で あると推定されている.

\section{3 牧田川第 13 床固工設置の「棚田式魚道」}

当該魚道は 2001 年に岐阜県大垣・養老地域を流孔る牧田 川の第 13 床固工に設置された（図 2）。牧田川第 13 床 固工は揖斐川との合流点から約 $12.2 \mathrm{~km}$ 上流にあり，全幅 $65.6 \mathrm{~m}$, 落差 $0.65 \mathrm{~m}$ となっている. 魚道は前述の魚道同様 に河道中央部にあり，河道，横断方向の大きさがそれぞ れ約 $6.2 \mathrm{~m}$ と約 $20.8 \mathrm{~m}$, プール段数が 6 段となっている. 近辺で見られる主な魚種は根尾川とほぼ同じであるとさ れており,この他に調査時にはエビ類（種名不明）やモ クズガニなども確認されている.

魚道下流部の左岸側には大規模な洲が形成されており， 左岸を流下寸る流孔は魚道の下流で大きく河道中央方向 に湾曲していた。このことから，魚道左岸部からの遡上 は見られないことが予想されたため, 稚アユの遡上が確 認される前に魚道下流 $30 \mathrm{~m}$ の土砂を移動させたが, 澪筋 は右岸側のままで大きくは変化しなかった。

調查は平成 14 年 7 月 3 日から 7 月 4 日にかけて行い, 時間は午前 5 時から午後 7 時までとした。調查期間は両日 ともに晴天であり, 日中の平均気温は初日が $28^{\circ} \mathrm{C}$ と二日 目が $29^{\circ} \mathrm{C}$ であった。水温は 5:30,10:30，13:00，17:00に 計測したが，両日とも午前中は $15^{\circ} \mathrm{C} \sim 16^{\circ} \mathrm{C}$, 午後は $18^{\circ} \mathrm{C}$ $\sim 19^{\circ} \mathrm{C}$ となった. 第 13 床固工の直上流部で計測した水 深は初日が $6 \mathrm{~cm}$ ，二日目が $5 \mathrm{~cm}$ となり，両日の流況はほ ぼ同じとなっていた，同年の 6 月に法本床固工の下流約 $1,000 \mathrm{~m}$ で, 河川水がすべて伏流化し, 断流が確認されて おり, 稚アユの遡上が阻害されていた。調查期間も流量 は平年流量を大きく下回る状況にあった。

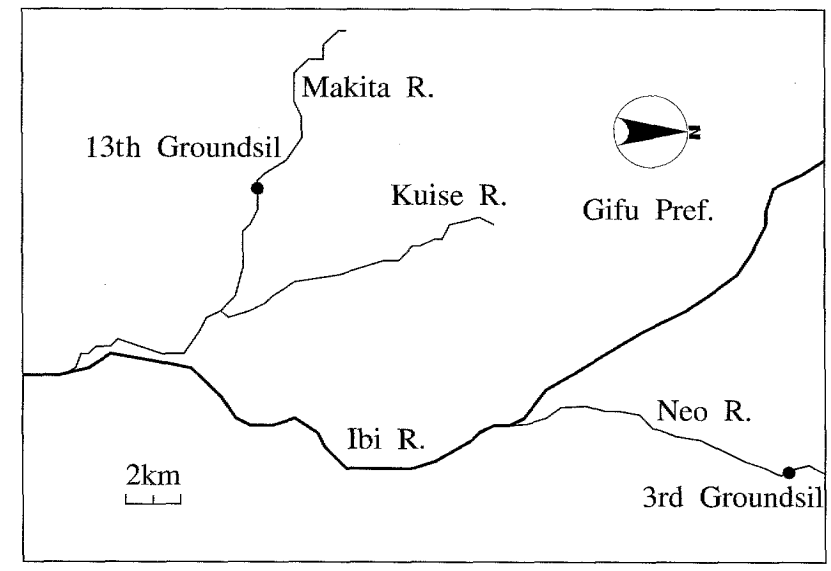

図 2: 対象魚道位置

\section{4 調查方法}

調査では, 棚田式魚道を土囊により, 左岸側, 中央部, 右 岸側の 3 経路に分離し，それぞれの経路を遡上するアニ の数を時刻とともに記録した。なお，それぞれの経路を 遡上するアユは誘導ネットによりビデオカメラの前を通 過するようになっており, 計測は右岸高水敷に設置され たモニターで行った. 計測数は 1 時間単位でとりまとめ た。アユに警戒させないために土囊の色は黒色とし，上 部が水面からわずかに出るように積み上げた（図 3〜7）.

\section{3 調査結果}

\section{1 根尾川第 3 床固エ}

調査初日は，調查開始からしばらくは遡上が見られず，正 午になってから遡上が確認されはじめた。午後は継続し て遡上が見られたが，14 時から遡上個体数が增えはじめ， 
16 時から 17 時の間にピークを迎えた。この時間帯には， 概水 5〜10 分毎に 5〜15 個体の群れの遡上が見られた。 こ の時閒帯の遡上個体数は当日の遡上個体総数の約 $25 \%$ を 占める結果となった。遡上経路については，15 時から 16 時までと 18 時から 19 時までの時間帯で左岸側の遡上経 路をとる個体が中央部を通過する個体よりも多かった以 外洼，中央部の遡上経路をとる個体が最も多く，1158 個 体，全体の 51\%を占めた。左岸側を遡上経路とした稚鮎 は 929 個体と全体の 41\%，右岸側については 188 個体と 全体の $8 \%$ であった.

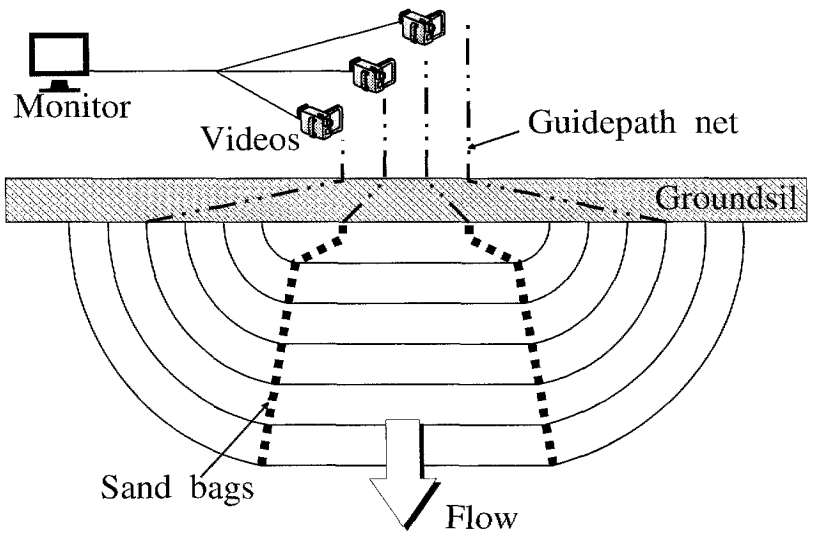

困 3: 調查設備概要

調查二日目は，前日同様に午前中に遡上が見られず， 12 時 50 分から遡上が確認されるようになった。午後は継続 して遡上が見られたが，18 時以降，急激に遡上個体数が 減少し，18 時 20 分にはほぼ皆無となった。この日最も多 くの遡上個体が見られたのは 14 時から 15 時までの時間 帯であり，当日の遡上個体数の $27 \%$ 占めた。遡上経路 については、左岸側の遡上経路をとる個体がいずれの時 間帯においても最多であり，続いて中央部、右岸側の順 となっている。左岸側, 中央部, 右岸側の経路を通過し た個体は，それぞれ 688 個体 $(65 \%) ， 267$ 個体 $(25 \%)$ ， 112 個体 $(10 \%)$ となった。

調查三日目では，遡上は 12 時から 17 時 20 分の間に 見られ，午前中および 17 時 20 分以降は全く確認されな かった。最も多く遡上が確認された時間带は14時から 15 時までであり，全体の $33 \%$ 占めた，遡上経路について は，左岸側からの遡上経路をとる個体が各時間帯におい て最多となっており，続いて中央部、右岸側の順になっ ている。1日全体としても左岸側を遡上経路とする個体 が最も多く，668 個体，全体の56\%となっている。また， 中央部と右岸側を遡上経路とした個体は，それぞれ，339 匹 $(29 \%) ， 177$ 個体（15\%）となった。（表 1, 図 8)

\section{2 牧田川第 13 床固工}

調查初日，稚アユの遡上が確認されたのは正午からの時 間帯で，午前中の遡上は確認されなか力た。12 時から 14 時までの時閒帯に多くの遡上が見られ，その割合は当日 の遡上確認個体数の 64\%になった. また, 17 時以降は遡 上が確認されなかった，遡上経路については，13 時から 14 時までの時間帯では右岸側からの遡上経路をとる個体 が多くみられたが，それ以外の時閒帯はす心゙て左岸側か らの遡上経路が最多となった。 中央部の経路をとる個体 数が最多となることはなかった。1 日を通して集計すれ ば，左岸側を逆上経路とする稚アコが 644 個体，全体の

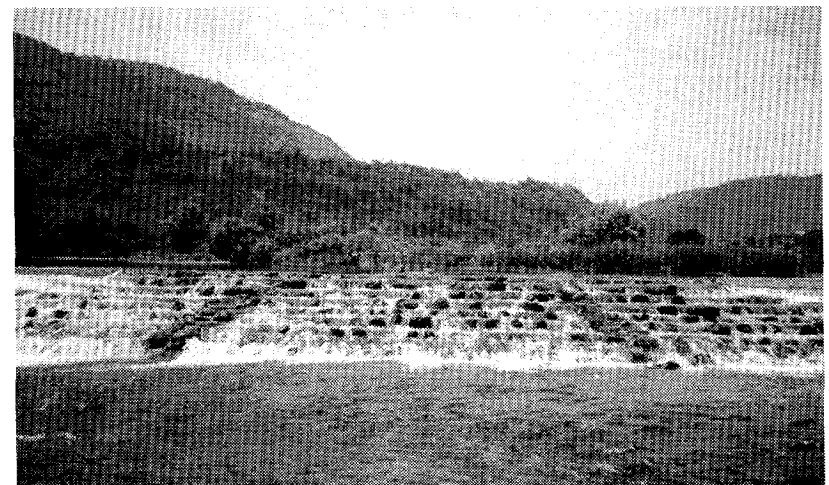

図 4: 土囊による遡上経路区分（根尾川第 3 床固工）

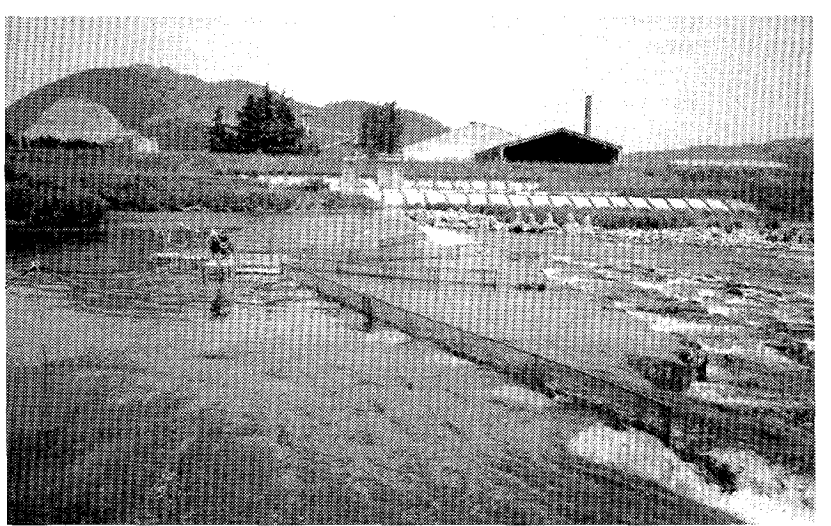

図 5: 調查設備全体（根尾川第 3 床固工）

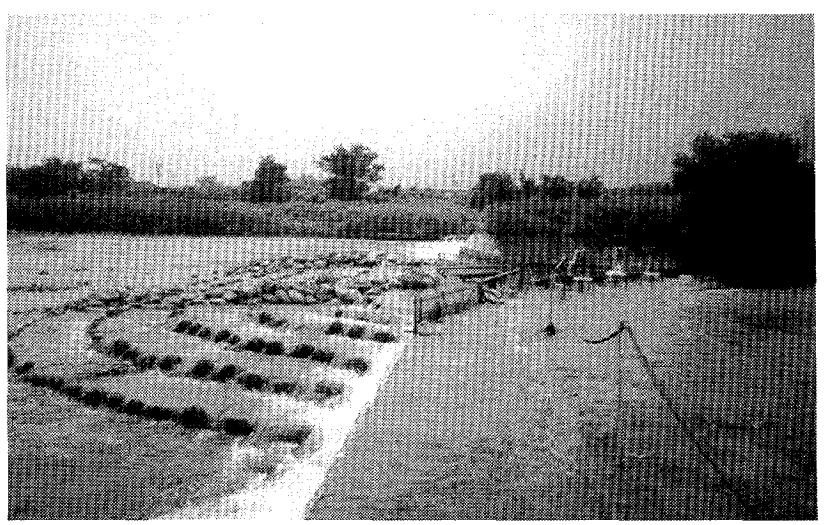

図 6: 調查設置状況（牧田川第 13 床固工）

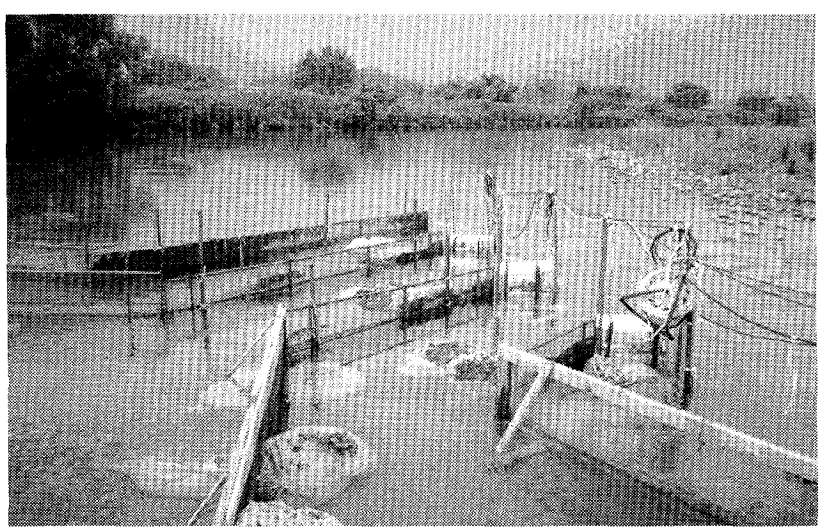

図 7: カメラ設置箇所（牧田川第 13 床固工） 
表 1: 第 3 床固工における稚アユの遡上時間帯と経路

\begin{tabular}{|c|c|c|c|c|c|}
\hline Term & Ratio in Term & Right & Center & Left & Total \\
\hline \multicolumn{6}{|l|}{$5 / 24$} \\
\hline $5: 00-12: 00$ & $0 \%$ & 0 & 0 & 0 & 0 \\
\hline $12: 00-13: 00$ & $6 \%$ & 11 & 60 & 60 & 131 \\
\hline $13: 00-14: 00$ & $3 \%$ & 2 & 52 & 9 & 63 \\
\hline $14: 00-15: 00$ & $19 \%$ & 46 & 223 & 160 & 429 \\
\hline $15: 00-16: 00$ & $24 \%$ & 33 & 253 & 266 & 552 \\
\hline $16: 00-17: 00$ & $25 \%$ & 30 & 367 & 174 & 571 \\
\hline $17: 00-18: 00$ & $7 \%$ & 20 & 98 & 44 & 162 \\
\hline $18: 00-19: 00$ & $16 \%$ & 46 & 105 & 216 & 367 \\
\hline Total & $100 \%$ & 188 & 1158 & 929 & 2275 \\
\hline \multicolumn{6}{|l|}{$5 / 25$} \\
\hline $5: 00-12: 00$ & $0 \%$ & 0 & 0 & 0 & 0 \\
\hline $12: 00-13: 00$ & $5 \%$ & 5 & 11 & 36 & 52 \\
\hline $13: 00-14: 00$ & $18 \%$ & 14 & 37 & 145 & 196 \\
\hline $14: 00-15: 00$ & $27 \%$ & 34 & 50 & 208 & 292 \\
\hline $15: 00-16: 00$ & $21 \%$ & 25 & 48 & 147 & 220 \\
\hline $16: 00-17: 00$ & $14 \%$ & 16 & 54 & 78 & 148 \\
\hline $17: 00-18: 00$ & $14 \%$ & 4 & 67 & 74 & 145 \\
\hline $18: 00-19: 00$ & $1 \%$ & 14 & 0 & 0 & 14 \\
\hline Total & $100 \%$ & 112 & 267 & 688 & 1067 \\
\hline \multicolumn{6}{|l|}{$5 / 26$} \\
\hline $5: 00-12: 00$ & $0 \%$ & 0 & 0 & 0 & 0 \\
\hline $12: 00-13: 00$ & $12 \%$ & 10 & 16 & 116 & 142 \\
\hline $13: 00-14: 00$ & $26 \%$ & 39 & 85 & 181 & 305 \\
\hline $14: 00-15: 00$ & $33 \%$ & 43 & 161 & 189 & 393 \\
\hline $15: 00-16: 00$ & $17 \%$ & 36 & 53 & 118 & 207 \\
\hline $16: 00-17: 00$ & $11 \%$ & 45 & 24 & 63 & 132 \\
\hline $17: 00-18: 00$ & $0 \%$ & 4 & 0 & 1 & 5 \\
\hline $18: 00-19: 00$ & $0 \%$ & 0 & 0 & 0 & 0 \\
\hline Total & $100 \%$ & 177 & 339 & 668 & 1184 \\
\hline
\end{tabular}

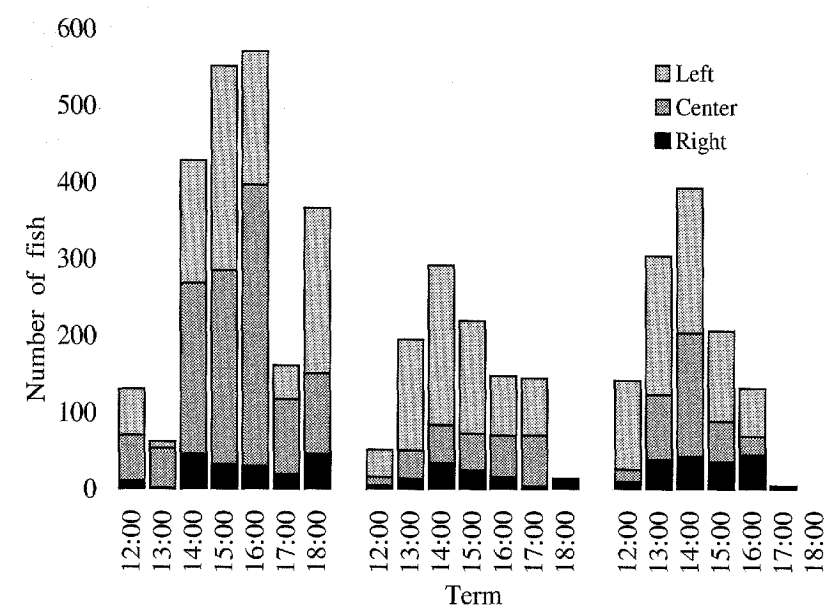

図 8: 遡上時間変化と遡上経路（根尾川）

50\%を占め, 中央部と右岸側の経路はそれぞれ，329 個 体，全体の 26\%と 306 個体，全体の 24\%であった。

調查二日目, 前日同様に 12 時から稚アユの遡上が始ま り，12 時から 17 時にかけて一様に遡上が確認できたが， 中では 12 時から 13 時までの遡上確認個体数が最も多く, 73 個体，この日全体の 26\%となった。遡上経路について は，左岸側からの遡上経路をとる稚アニがいずれの時間 帯においても最多となっており，続いて存岸側，中央部 の順となっている. 1 日を通した集計では, 左岸側を遡上
経路とする稚アユが 730 個体となり，全体の 54\%を占め, 右岸側および中央部は，316 個体（同 24\%）と 293 個体 （同 22\%）となった.（表 2, 図 9)

表 2: 第 13 床固工における稚アユの遡上時間帯と経路

\begin{tabular}{cccccc}
\hline Term & Ratio in Term & Right & Center & Left & Total \\
\hline 5/25 & & & & & \\
5:00-12:00 & $0 \%$ & 0 & 0 & 0 & 0 \\
12:00-13:00 & $35 \%$ & 53 & 117 & 276 & 446 \\
13:00-14:00 & $29 \%$ & 174 & 73 & 121 & 368 \\
14:00-15:00 & $17 \%$ & 35 & 68 & 111 & 214 \\
15:00-16:00 & $7 \%$ & 8 & 23 & 54 & 85 \\
16:00-17:00 & $13 \%$ & 36 & 48 & 82 & 166 \\
17:00-18:00 & $0 \%$ & 0 & 0 & 0 & 0 \\
Total & $100 \%$ & 306 & 267 & 644 & 1279 \\
\hline WII & & & & & \\
5:00-12:00 & $0 \%$ & 0 & 0 & 0 & 0 \\
12:00-13:00 & $26 \%$ & 73 & 92 & 186 & 351 \\
13:00-14:00 & $14 \%$ & 45 & 26 & 119 & 190 \\
14:00-15:00 & $21 \%$ & 45 & 106 & 130 & 281 \\
15:00-16:00 & $14 \%$ & 47 & 33 & 104 & 184 \\
16:00-17:00 & $25 \%$ & 106 & 36 & 191 & 333 \\
17:00-18:00 & $0 \%$ & 0 & 0 & 0 & 0 \\
Total & $100 \%$ & 316 & 293 & 730 & 1339 \\
\hline
\end{tabular}

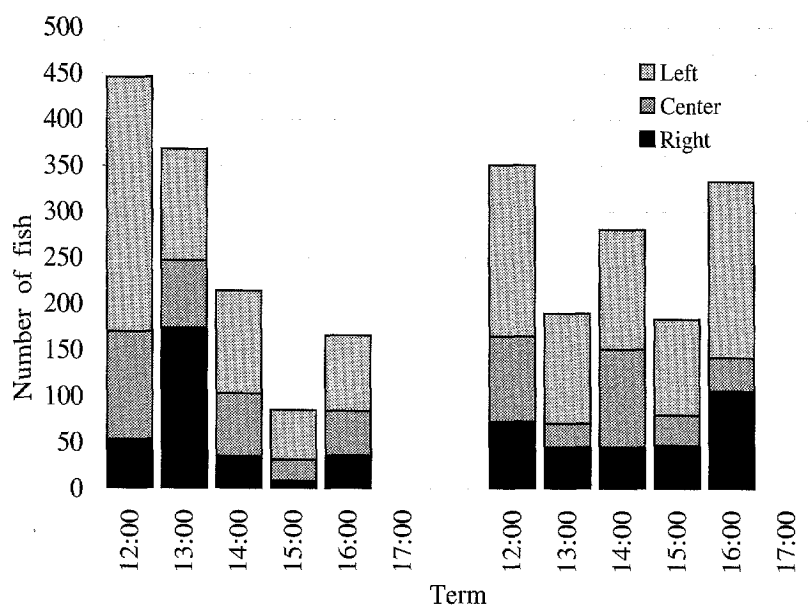

図 9: 遡上時間変化と遡上経路（牧田川）

\section{4 考察}

根尾川第 3 床固工に設置した焦道における調査では，右 岸側から遡上した個体が全体の $11 \%$, 中央が $39 \%$, 左岸 側が 50\%という結果となった。前述の通り，第 3 床固工 には右岸部に既設の魚道があり,さらに，その下流部に 堆砂が見られた。結果として，魚道付近の流れは中央と 左岸部に集中し，数十 $\mathrm{m}$ 下流で右岸方向にも桩がる形に なっていた。すなわち，右岸側を遡上してきた個体群は， 堆砂部を迁回するように，魚道のやや下流で中央方向に 向きを変える必要があったものと考光られる。

次いで，牧田川第 13 床固め工に設置した魚道における 調查では，右岸側から遡上した個体が全体の $24 \%$ ，中央 が $24 \%$, 左岸側が $52 \%$ という結果となった. 第 13 床固 工では, 澪筋が右岸側に形成されていることから, 稚ア ユは強い流れを避け, 左岸側から多く遡上したものと考 えられる。 
両魚道を通じて，右岸側と左岸側から遡上した個体は 全体の $66.6 \%$ 占める。左岸から魚道左岸部までの間の 床固工段差に到達した個体は，到達後に河川横断方向に 移動して左岸側から魚道に侵入乙, 右岸側から魚道右岸 部までの部分に到達した個体注右岸側から，中央の経路 の入り口約 $15 \mathrm{~m}$ の間に到達した個体は中央から魚道に侵 入すると考えられるとすれば，魚道入り口が下流側に突 出した旧来型の魚道であれば遡上できなかったであろう 個体を相当数遡上させていることになる. 右岸側と左岸 側のいずれからの遡上個体数が多くなるかは澪筋などの 流れの状況に強く影響されており，さらに自然河川にお いて澪筋は時間に応じて場所を変えることが多いが，本 魚道のように河道に対してシンメトリックな形状を持つ 魚道であれば，このような澪筋の変化に対応がしやすい． 右岸側と左岸側の両者を合わせて考えると, 流れの状況 あるいは澪筋に拘わらず，遡上個体を集めることが可能 であり，扇形状あるいはそれに類似する形状の開口部は 有効であると結論づけられる.

アユの遡上行動には, 水温, 水位, 照度などの外的要 因, アユ自体の集団密度や栄養状態などの内的要因, 落 水などの外的刺激要因が関係しているとされている（た とえば，戸井, 1999)。.また，海からの遡上行動には，こ の他に海水温度，塩分濃度，濁度などが関係していると 考えられている（たとえば, 嶋田ら, 2006）。今回の調查 では, 計測した項目が, 現地における気温, 水温および 水深のみであったため, 厳密にアユの遡上特性を把握寸 ることは困難であるが， 2 箇所，延心゙ 5 日閒の調查を通 じて，一定の共通点が確認できた。 そのうち最も明確な 点として，いずれの調查日においても稚アユの遡上が確 認できたのは午後であったということが挙げられる. 根 尾川と牧田川の調査時期には 1 ヶ月強の差があるが, 午前 中は水温情 $15^{\circ} \mathrm{C}$ から $16^{\circ} \mathrm{C}$ まで, 午後の水温は $18^{\circ} \mathrm{C}$ か ら $19^{\circ} \mathrm{C}$ までとなっており，大きな差は見られなかった。 このことから, 稚アユの遡上は水温に依存している可能 性が考えられるが, 去年までの根尾川における予備調査

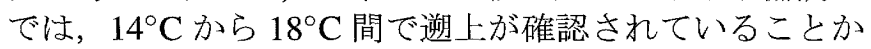
ら，その依存性は限定的であると考えられる。ささらには 根尾川の 5 月 24 日の調查以外では, 日没直前に急激に遡 上個体数が減少していること, 5 月と 7 月の調查を比較 すると日没の早い 7 月の方が遡上の終了時間が早いこと から, これらの魚道における稚アユの遡上は, 日没と強 い関係を持ち，すなわち水温以外にも照度あるいは時間 帯等に强く依存しているのではないかと推察される.

棚田式魚道における遡上調查の結論をまとめると, 次 のようになる。

1) 遡上個体総数の $66.6 \%$ 古岸側および左岸側から魯道 に侵入しており，扇形形状あるいはとれに準ずる形状 の魚道開口部が稚アユの魚道誘導に有効であることが 明らかになった．右岸側あるいは左岸側のいずれから 遡上するかについては, 流れの状態や澪筋の位置によ り規定されるが，扇形状あるいはそれに類する形状の 魚道が河道中央部に設置されている場合は，全体とし ての遡上個体総数には影響を受けないと考えられる。

2）今回対象となったような比較的上流部に位置する魚道 においては，午前中の遡上は見られない，あるいは極
めて少数であり, 遡上は正午から日没前の午後 5 時前 後までに集中する.

3) 第 3 床固工での調查時には午後 2 時前後に遡上数が増 加したことが見て取れるが，第 13 床固工では正午か ら午後 1 時の間に遡上数が最大となっており, 遡上が 見られる時間帯における遡上数分布については明確な 傾向を見ることは出来ない.

4）稚アユが遡上を試みる条件として，絶対的な水温以外 に午前と午後の水温差なども影響している可能性があ ること，照度あるいは時間帯等にも依存していること が推察される。

5）今回, 床固工下流部に到達した稚アユのうち, どの程 度が魚道に侵入したかといった客観的な判断材料はな いが，調査 5 日間を通じてす心゙ての調查日において 1,000 個体以上の遡上が確認されたことにより，プー ルタイプとストリームタイプのハイブリットである棚 田式魚道は一定の機能を果たしていると考えられる. すなわち，今回の床固工のように比較的高低差の少な い河川横断構造物の段差部に設置する魚道として同形 式の魚道は有効であるといえる.

アユが漁業対象魚であることから, 調査時期や調查方 法に法制限がかけられており, 結果として, 得られた知 見は限定的となってはいるが，扇形に準じる形状である 「棚田式魚道」での稚ア二遡上状況之侵入経路および開口 部形状の効果が明らかになった. 今後も調査を継続し, 魚 道の効果をより定量的な形で明らかにするとともに，よ り一層の改善についても検討を加えていく必要がある.

\section{謝辞}

本研究を遂行するにあたり，国土交通省中部地方整備局 木曾川上流河川事務所には椂々な便宜を図っていただく とともに，情報も提供して頂いた。 また，調査には山辰 組社員ならびに岐阜大学学生の協力を得た。ここに記し て謝意を表する。

\section{引用文献}

[1] Clay, C. H.(1995):Design of fishways and other fish facilities Second Edition, CRC Press, p.4.

[2] ドイツ水資源・農業土木協会 (1996): 多自然型魚道マニュア ル, リバーフロント整備センター訳, 山海堂, p.33.

[3] Fujihara, M. and Fujita, A. (2008): A simple estimation method of flow structure in a fan-shaped fishway, JRCSA, 14(2), pp. 29-33.

[4] 馬㴊和三・平松研・板垣博 (2003):「棚田式魚道」の水理 特性と有効性に関寸る検証，日本雨水資源化システム学会 誌, 9(1), pp.37-42.

[5] 嶋田啓一・後藤浩一 - 山本一生・和田吉弘 (2006)：長良 川に抢ける稚アユ遡上量の予測に関する检討, 日本水産学 会誌, 72(4), pp.665-672.

[6] 戸井真一郎 (1999)：アユによる魚道遡上条件の検討, 広水 試研報, 20, pp.5-9.

[7] 和田吉弘 (2003) : 魚道見聞録, 山海堂, pp.36-37.

[8] (財) ダム水源地環境整備センター (1991): 魚道の設計, 山海堂, pp.170-171. 